\title{
Membangun Kerukunan Antarumat Beragama dan Implikasinya bagi Misi Kristen
}

\author{
Yonatan Alex Arifianto ${ }^{1}$; Kalis Stevanus ${ }^{2}$ \\ Sekolah Tinggi Teologi Sangkakala Salatiga ${ }^{1}$; Sekolah Tinggi Teologi Tawangmangu ${ }^{2}$ \\ Korepondensi: arifianto.alex@sttsangkakala.ac.id; kalisstevanus91@gxmxail.com
}

\begin{abstract}
Abstrak: Indonesia adalah bangsa yang majemuk karena terdiri dari berbagai suku, bahasa, budaya dan agama. Kemajemukan memiliki potensi konflik horisontal di masyarakat. Yesus memerintahkan agar orang Kristen mewujudkan kasih kepada sesama seperti kepada diri sendiri. Kasih yang tulus akan menciptakan kerukunan dan keharmonisan dengan sesama tanpa memandang perbedaan yang ada di dalamnya. Penelitian ini menggunakan metode kualitatif deskriptif melalui menggali literatur yang berkaitan dengan topik dan menggunakan teks-teks paralel Alkitab yang mendeskripsikan bagaimana orang percaya menjalankan panggilan untuk hidup rukun sekaligus mengemban misi Kristen untuk menyelamatkan mereka yang belum percaya pada Kristus. Melalui penelitian ini disimpulkan bahwa misi Kristen adalah penerapan dari kasih Kristus. Kasih itu menjadi dasar dalam bermasyarakat untuk menumbuhkembangkan sikap toleransi dan saling menghormati hak-hak setiap orang termasuk berkeyakinan. Realitas ini harus mengubah paradigma dan praktik dari misi Kristen modern. Misi Kristen harus tetap berpegang teguh pada Alkitab yang menegaskan bahwa iman dalam Kristus sebagai persyaratan mutlak keselamatan. Tetapi tidak ada alasan bagi orang percaya atau gereja untuk tidak menjalankan perintah misioner tersebut dengan tetap menjaga kerukunan beragama agar dapat menjadi berkat bagi orang yang belum mengenal Kristus.
\end{abstract}

Kata kunci: implikasi, misi Kristen, majemuk, rukun

\begin{abstract}
Indonesia is a pluralistic nation because it consists of various races, languages, cultures, and religions. Diversity has the potential for horizontal conflict in society. Jesus commanded that Christians manifest love for others as well as for themselves. Sincere love will create harmony and harmony with others regardless of the differences in it. This research uses a descriptive qualitative method through exploring literature related to the topic and using parallel biblical texts that describe how believers carry out their call to live in harmony and at the same time carry out a Christian mission to save those who do not believe in Christ. From this research, it is concluded that the Christian mission is the application of the love of Christ. Love is the basis in society to foster tolerance and mutual respect for the rights of everyone, including belief. This reality must change the paradigm and practice of modern Christian mission. Christian mission must stick to the Bible which affirms that faith in Christ is an absolute requirement of salvation. Therefore, there is no reason for the believer or the church not to carry out this missionary command by maintaining religious harmony so that it can be a blessing for those who do not know Christ.
\end{abstract}

Keywords: implication, Christian mission, compound, get along well 


\section{PENDAHULUAN}

Konflik horizontal dalam sejarah pertikaian antarumat beragama maupun suku pasca era reformasi sangat membekas. Hal tersebut dipicu oleh persoalan agama yang mengarah kepada sentimen keagamaan dalam ranah politik praktis, ${ }^{1}$ menghina dan melecehkan secara verbal maupun non verbal terhadap keyakinan dan nilai ajaran agama yang diyakini oleh agama lain. ${ }^{2}$ Terlebih lagi adanya tindakan pembakaran fasilitas umum ibadah yang dilindungi pemerintah. Selain itu, adanya hubungan yang tidak harmonis serta berdampak negatif terhadap kerukunan antarumat beragama dan adanya indikator munculnya perasaan saling mencurigai dan saling membenci. ${ }^{3}$ Ada juga tindakan anarkis terhadap agama dan penghinaan serta pelecehan kepada pemimpin rohani sebuah agama tertentu, serta tindakan yang tidak mengayomi, tidak adilnya aparat, kecemburuan ekonomi dan perbedaan pendapat berujung konflik kepentingan politik yang bertujuan untuk menciptakan ketidakharmonisan dalam kerukunan umat beragama. ${ }^{4}$ Keadaan yang demikian berdampak pada kerukunan yang dapat terkikis dan menjadi petaka bila ada pembiaran terhadap praktik-praktik intoleransi dan radikalisme, yang berpotensi mengancam stabilitas keamanan dan integritas bangsa dan negara. ${ }^{5}$ Masyarakat multikultural di Indonesia, isu mayoritas dan minoritas, dan pertikaian antar suku seperti yang terjadi di Kalimantan,

${ }^{1}$ Ari Ganjar Herdiansah, Junaidi -, dan Heni Ismiati, "Pembelahan Ideologi, Kontestasi Pemilu, dan Persepsi Ancaman Keamanan Nasional: Spektrum Politik Indonesia Pasca 2014?," Jurnal Wacana Politik 2, no. 1 (Juni 14, 2017): 61-73.

${ }^{2}$ Mochamad Guruh Abdi Priatna dan Hernawati RAS, "Tindak Pidana Penodaan Agama oleh Pemeluknya Melalui Media Internet Berdasarkan Undang-Undang Nomor 19 Tahun 2016 Tentang Perubahan Atas UndangUndang No 11 Tahun 2018," WACANA PARAMARTA: Jurnal Ilmu Hukum 16, no. 3 (2017): 139-148.

${ }^{3}$ Ahmad Sodli, "Kerukunan Umat Beragama Di Provinsi Nusa Tenggara Timur (NTT)," Analisa: Journal of Social Science and Religion 16, no. 1 (2009): 64-73.

${ }^{4}$ Khotimah Khotimah, "Toleransi Beragama," Jurnal Ushuluddin 20, no. 2 (2013): 212-222.

${ }^{5}$ Institut Setara, Dari Radikalisme Menuju Terorisme (Jakarta: Pustaka Masyarakat Setara, 2015), 2.
Ambon dan Papua merupakan isu yang dikemukakan sebagai trigger yang memicu terjadinya konflik-konflik maupun isu SARA lainnya. ${ }^{6}$ Jamaludin mengungkapkan bahwa dari pasca reformasi tahun 1998, pertikaian antarumat beragama di Indonesia semakin menunjukkan intensitasnya. ${ }^{7}$

Berkaitan dengan topik Membangun Misi dalam Kerukunan juga pernah diteliti oleh Megawati Manullang dengan penelitian misi dalam masyarakat majemuk. ${ }^{8}$ Kesimpulan dari penelitian tersebut adalah bahwa penginjilan sebagai salah satu tugas esensial gereja dan salah satu tugas yang tidak mungkin ditiadakan dari kehidupan orang Kristen dalam masyarakat majemuk. Fransiskus Irwan Widjaja melakukan penelitian serupa dalam artikel berjudul Pluralitas dan Tantangan Misi: Kerangka Konseptual untuk Pendidikan Agama Kristen dalam Masyarakat Majemuk ${ }^{9}$ dengan kesimpulan bahwa misi berfokus kepada strategi penginjilan dalam konsep Pendidikan Agama Kristen. Berdasarkan kedua penelitian tersebut masih ada hal-hal yang belum diteliti yaitu tentang peran orang percaya dalam membangun kerukunan umat beragama yang diimplikasikan pada misi Kristen Oleh sebab itu artikel ini akan meneliti dan membahas tentang topik tersebut.

Sebagaimana diungkapkan Stevanus bahwa kemajemukan atau pluralitas itu memiliki potensi konflik sosial yang jika tidak dicegah dengan segera dapat meruntuhkan sendi-sendi dalam berkehidupan sosial. $^{10}$ Keberagaman kerap menjadi sumber persoalan dalam

${ }^{6}$ Adon Nasrullah, Agama dan Konflik Sosial: Studi Kerukunan Umat Beragama, Radikalisme dan Konflik Antarumat Beragama (Bandung: CV. Pustaka Setia, 2015), 147.

${ }^{7}$ Ibid.

${ }^{8}$ Megawati Manullang, "Misi dalam Masyarakat Majemuk," Jurnal Teologi Cultivation 3, no. 2 (2019): 4963.

${ }^{9}$ Fransiskus Irwan Widjaja, "Pluralitas Dan Tantangan Misi: Kerangka Konseptual untuk Pendidikan Agama Kristen dalam Masyarakat Majemuk," REGULA FIDEI: Jurnal Pendidikan Agama Kristen 4, no. 1 (2019): 1 13.

${ }^{10}$ Kalis Stevanus, "Memaknai Kisah Orang Samaria Yang Murah Hati Menurut Lukas 10:25-37 Sebagai Upaya Pencegahan Konflik," BIA': Jurnal Teologi dan Pendidikan Kristen Kontekstual 3, no. 1 (2020): 1-13. 
kehidupan masyarakat Indonesia. Ujaran kebencian atas nama agama, suku dan kepercayaan dan juga aksi berbagai intoleransi sering terjadi. ${ }^{11}$ Bahkan hubungan antarumat beragama atau kepercayaan dari sejak dulu selalu mengalami pergerakan yang tidak stabil. Hal itu disebabkan adanya masalah sosial yang mengklaim bahwa ajaran agamanya paling benar dan memunculkan sikap antipati, bahkan satu sama lain saling menghina dan meremehkan. ${ }^{12}$

Dengan latar belakang permasalahan yang terjadi, maka tujuan penelitian ini adalah untuk memberikan pemahaman kepada orang percaya agar memberikan respon terhadap kerukunan dengan menjadi pribadi yang aktif dalam menjunjung tinggi dan menjadi pelopor kerukunan tersebut.

\section{METODE}

Metode yang digunakan dalam penelitian ini adalah kualitatif deskriptif, ${ }^{13}$ dengan pendekatan studi literatur yang berkaitan dengan konsep kerukunan umat manusia sebagai dasar dalam membangun misi dalam masyarakat majemuk dan multikultural. Beberapa teks paralel Alkitab yang mendukung konsep kerukunan juga diselidiki untuk mendapatkan informasi deskriptif tentang makna kerukunan dan sebagai bagian dari misi Kristen. Penulis juga mendeskripsikan kerukunan yang berkaitan dengan kondisi masyarakat heterogen Indonesia, yang dimaknai dan diimplikasikan bagi misi Kristen berdasarkan firman Tuhan sebagai tanggung jawab orang percaya menciptakan kerukunan umat manusia dan juga melaksanakan misi Kristen di tengah kemajemukan.

${ }^{11}$ Rikardo Dayanto Butar-Butar dkk., "Pengajaran Tuhan Yesus Mengenai Toleransi dan Implementasinya Ditengah Masyarakat Majemuk,” REAL DIDACHE: Jurnal Teologi dan Pendidikan Agama Kristen 4, no. 1 (2019): 88101.

${ }^{12}$ Ujang Saefullah, "Dinamika Komunikasi dalam Mewujudkan Kerukunan Hidup Antarumat Beragama," Ilmu Dakwah: Academic Journal For Homiletic Studies 5, no. 1 (2011): 411-444.

${ }^{13}$ Conny R. Semiawan, Metode Penelitian Kualitatif (Jakarta: Grasindo, 2010), 60.

\section{PEMBAHASAN}

Menghargai umat manusia dan menghormati hak asasinya secara utuh, baik saat beribadah maupun dalam kehidupan sehari-hari adalah tujuan penting dari sikap dan tindakan dari martabat manusia. ${ }^{14}$ Sependapat dengan hal tersebut Sairin menyatakan bahwa Negara Republik Indonesia adalah negara yang beragam dan besar serta mempunyai ciri khas kemajemukan dalam bermasyarakat dan keberadaan Indonesia juga adalah anugerah agung yang Tuhan berikan untuk dijaga dan dirawat, serta dipelihara sebagai bagian dari anak bangsa. ${ }^{15}$ Akar konflik horizontal antarumat beragama adalah tidak adanya kerendahan hati dan kesadaran tentang beragama yang benar dari sumber yang tidak dapat dimengerti dan ketidaktahuan atau kekurangpahaman terhadap keyakinan ajaran agamanya sendiri, terlebih kepercayaan orang lain. ${ }^{16}$

Semua manusia beragama diharapkan memberi peran dan kontribusi yang dapat di implementasikan bagi pembangunan nasional yang dilaksanakan bangsa Indonesia. Nilai-nilai kerohanian dan agama dapat memberikan semangat yang baik dan menjadi nilai serta tujuan dalam seluruh kegiatan yang dikerahkan untuk pembangunnan bangsa. Unity dan kerjasama dalam umat beragama sangat diharapkan menjadi bagian penting dalam menjalin hubungan. Sebab sejatinya toleransi dalam masyarakat majemuk diajarkan untuk mendasari kerukunan dalam bermasyarakat dan antarumat beragama. ${ }^{17}$

Sejatinya kerukunan tidak diperoleh dari aturan-aturan yang bersifat eksternal, yaitu dengan mengupayakan melalui aturan

${ }^{14}$ Weinata Sairin, Kerukunan Umat Beragama Pilar Utama Kerukunan Berbangsa: Butir-Butir Pemikiran (Jakarta: BPK Gunung Mulia, 2006), 9.

${ }^{15}$ Weinata Sairin, Visi Gereja Memasuki Milenium Baru (Jakarta: BPK Gunung Mulia, 2002), 125.

${ }^{16}$ Khotimah Khotimah, "Dialog dan Kerukunan Antar Umat Beragama," Jurnal Ushuluddin 17, no. 2 (2011): 214-224.

${ }^{17}$ Nazmudin Nazmudin, "Kerukunan dan Toleransi Antar Umat Beragama dalam Membangun Keutuhan Negara Kesatuan Republik Indonesia (NKRI)," Journal of Government E Civil Society 1, no. 1 (2017): 23-39. 
perundang-undangan, tetapi dihasilkan secara original yang tumbuh dari dalam pengejahwantahan kepercayaan pribadi lepas pribadi dan melalui dinamika perjumpaan antarumat beragama dan keyakinan yang berbeda. ${ }^{18}$ Sehingga segala kerukunan antarumat beragama maupun antar suku dapat terwujud dan memberikan kebergunaan bagi bangsa, dengan menyingkirkan sentimen sukuisme, agama, maupun adat istiadat yang dipertentangkan. ${ }^{19}$ Kerukunan adalah panggilan iman dan kesadaran internal yang didorong oleh kasih. ${ }^{20}$ Terlebih kesadaran dalam menjalankan agama dan keyakinan bisa menjadi langkah awal menuju konsep toleransi antar maupun inter umat beragama. Demikian juga yang terpenting adalah dapat menanamkan kesadaran beragama, sebab kesadaran ini menjadi nilai yang hakiki dan mutlak dari kemanusiaan yang universal. ${ }^{21}$ Kerukunan yang hakiki harus dilandasi oleh nilai-nilai universalitas dan misi kemanusiaan. ${ }^{22}$ Penting sekali untuk memiliki ciri hidup dalam kebersamaan yang rukun dengan kesatuan hati, pikiran dan setuju untuk tidak menciptakan konflik kepentingan serta pertengkaran dalam wujud apapun. Ini karena menjalankan hidup penuh dengan kebersamaan adalah impian semua orang. Perbedaan juga bisa menjadi landasan kekuatan bila dapat dikelola dengan baik dan profesional. Namun, jika tidak, perbedaan pandangan multikultural akan menjadi indikasi disintegrasi bangsa dan konflik

${ }^{18}$ Setyo Pamungkas, "Mengkritisi RUU Kerukunan Umat Beragama: Menjamin Atau Membatasi Kebebasan?," Refleksi Hukum: Jurnal Ilmu Hukum 8, no. 1 (2014): 103114.

${ }^{19}$ Yonatan Arifianto, "Deskripsi Sejarah Konflik Horizontal Orang Yahudi dan Samaria," PASCA: Jurnal Teologi dan Pendidikan Agama Kristen 16, no. 1 (Mei 29, 2020): 33-39.

${ }^{20}$ A. A. Yewangoe, Agama dan Kerukunan (Jakarta: BPK Gunung Mulia, 2015), 33.

${ }^{21}$ Khotimah, "Dialog dan Kerukunan Antar Umat Beragama."

${ }^{22}$ Saidurrahman dan Arifinsyah, NALAR KERUKUNAN: Merawat Keberagaman Bangsa Mengawal NKRI (Jakarta: KENCANA, 2018), 65. yang berkepanjangan. ${ }^{23}$ Oleh sebab itu, agama mempunyai peran penting dalam meminimalisir jurang sekularisme yang akan mengakibatkan disintergrasi dalam berbagai konflik kehidupan masyarakat dalam beragama dan bernegara.

Toleransi beragama merupakan sikap dan pandangan yang mencakup masalah-masalah keyakinan dalam diri manusia yang berhubungan dengan ajaran, nilai dan norma atau ketuhanan yang diyakininya. Setiap orang harus dihormati dan diberikan kebebasan untuk meyakini dan memeluk agama serta melaksanakan ajaran-ajaran yang dianut atau diyakininya. ${ }^{24}$ Toleransi memiliki esensi sikap saling menghormati, saling menerima, saling menghargai di tengah keragaman budaya, kebebasan berekspresi dan karakter manusia. ${ }^{25}$ Oleh sebab itu, orang percaya yang taat terhadap pemerintah melalui perundang-undangan dapat memiliki sikap memprioritaskan kerukunan dan menjembatani misi Kristen bagi masyarakat majemuk.

\section{Sikap Orang Percaya terhadap Toleransi}

Keberagaman yang diwariskan menjadi alat pemersatu bangsa dan membawa nilai kerukunan untuk membangun bangsa. Tetapi dalam menjalani kehidupan bermasyarakat, kemajemukan hakiki yang ditandai dengan keanekaragaman agama maupun kepercayaan yang sangat beragam tersebut, dapat menjadi pudar akibat dari minimnya pengetahuan agama dalam mengaktualisasi kerukunan. Keadaan tersebut seringkali menjadi tempat disintegrasi yang berujung pada diskriminasi dan intoleransi serta dapat menghilangkan nilai persaudaraan yang dapat merusak nilai kebersamaan dan kerukunan dalam kemajemukan bangsa Indonesia yang multikultural. Kerukunan adalah sebuah faktor penting dalam kemajemukan

${ }^{23}$ Kiki Mayasaroh, “Toleransi Strategi dalam Membangun Kerukunan Antarumat Beragama di Indonesia," al-Afkar: Journal For Islamic Studies 3, no. 1 (2020): 77-88.

${ }^{24}$ Casram Casram, "Membangun Sikap Toleransi Beragama dalam Masyarakat Plural," Wawasan: Jurnal Ilmiah Agama dan Sosial Budaya 1, no. 2 (2016): 187-198. ${ }^{25}$ Ibid. 
bangsa. Tanpa kerukunan maka bangsa akan tercerai-berai dan memicu konflik hubungan horizontal dan menjadikan masyarakat bertindak intoleran. Konsep kasih dari pengajaran Yesus yang bertujuan mengasihi musuh sejatinya dapat membawa perubahan dalam pribadi orang percaya untuk diaplikasikan dalam masyarakat multikultural. ${ }^{26}$

Sairin mengungkapkan jika orang percaya dalam membangun dan menjaga kerukunan didasarkan pada tindakan diskriminasi, segresi dan apartheid maka kerukunan yang diciptakan adalah kerukunan yang palsu, jahat dan amoral sebab tidak didasari pada kasih, kebenaran, keadilan dan kebebasan. ${ }^{27}$ Untuk itu orang percaya dapat mengejawantahkan nilai kerukunan berdasarkan kasih bagi manusia dan terlebih bagi orang yang memusuhi. Yesus memberikan contoh bahwa Ia sangat toleran dengan sesama. Ia peduli dan menerima siapa pun yang tiada mendapat tempat di masyarakat, misalnya faktor keyakinan dan etnis (orang-orang Samaria). ${ }^{28}$

Hal ini akan berdampak pada kedamaian yang dapat memberikan kebahagiaan seperti yang diungkapkan Matius yaitu "berbahagialah orang yang membawa damai” (Mat. 5:9). Orang percaya juga diharapkan untuk berdamai terlebih dahulu ketika ada dalam konflik sehingga kebersamaan itu akan membawa manfaat bagi pribadinya, seperti yang diungkapkan Yesus dalam Matius 5:25 "Segeralah berdamai dengan lawanmu selama engkau bersama-sama dengan dia di tengah jalan..."

Dalam prespektif iman Kristen, perbedaan kemajemukan masyarakat Indonesia adalah anugerah Tuhan dan kekayaan besar bangsa yang wajib dijaga dan disyukuri. Keberagaman suku, bangsa, ras serta agama adalah keunggulan dan

${ }^{26}$ Yudi Hendri Lia, Reni Triposa, dan Gloria Gabriel Lumingas, "Menciptakan Kerukunan Umat Beragama dalam Masyarakat Majemuk Melalui Pemaknaan Kasih Berdasarkan Matius 5:43-44,” PNEUMATIKOS: Jurnal Teologi/Kependetaan 11, no. 1 (2020): 61-70.

${ }^{27}$ Sairin, Kerukunan Umat Beragama Pilar Utama Kerukunan Berbangsa: Butir-Butir Pemikiran, 20.

${ }^{28}$ Kalis Stevanus, "Mengimplementasikan Pelayanan Yesus dalam Konteks Misi Masa Kini Menurut Injil Sinoptik," FIDEI: Jurnal Teologi Sistematika dan Praktika 1, no. 2 (2018): 284-298. kekuatan Indonesia sebagai bangsa yang besar. Gereja atau orang percaya harus bertanggung jawab dan berpartisipasi dalam merawat kemajemukan agama sehingga damai sejahtera Allah di bumi dapat terwujud. ${ }^{29}$ Pusat dari kekristenan itu sendiri yang menjadikan hukum terutama yaitu mengasihi Tuhan Allah setara dengan mengasihi sesama manusia.

Yesus Kristus sebagai tokoh sentral iman Kristen dalam praktik hidup pelayanan dan pengajaranNya mewariskan nilai luhur tentang toleransi. Oleh sebab itu Alkitab, baik Perjanjian Lama dan Perjanjian Baru, adalah sumber utama bagi pandangan dan sikap Kristen dalam hidup bermasyarakat. Yesus sendiri menjadi teladan dalam menghargai pluralisme dan bertoleransi.

Pesan Tuhan Yesus dalam kitab Matius juga menyebutkan: "Segala sesuatu yang kamu kehendaki supaya orang perbuat kepadamu, perbuatlah demikian juga kepada mereka. Itulah isi seluruh hukum Taurat dan kitab para nabi" (Mat. 7:12). Dari apa yang dikatakan Yesus, maka orang percaya harus memiliki sikap dapat menerima, menghargai dan mengasihi sesama manusia. Ini merupakan inti dari pengajaran Yesus yang harus dikerjakan dan dihidupi oleh setiap orang Kristen. Segala hal yang berkaitan dengan kebencian dan tindakan intoleransi tidak ada tempat dalam kesaksian kekristenan yang berdasarkan pengajaran Alkitab. Toleransi harus menjadi prioritas dan kebutuhan utama dalam membangun masyarakat yang baik. Orang percaya harus mengasihi orang lain seperti diri sendiri serta menerima, menghargai dan menghormati sesama, apapun agama dan kepercayaannya.

\section{Kerukunan dalam Tinjauan Hukum Negara}

Keberagaman atau perbedaan yang terjadi
dalam proses bermasyarakat sangat memengaruhi bahasa, suku, budaya, serta nilai kerohanian tentang kepercayaan. Secara sosial, bangsa Indonesia adalah masyarakat yang

${ }^{29}$ Butar-Butar dkk., "Pengajaran Tuhan Yesus Mengenai Toleransi dan Implementasinya Ditengah Masyarakat Majemuk." 
memiliki nilai agama yang tinggi $^{30}$ dan masyarakatnya menanamkan nilai kebersamaan dan kemajemukan secara utuh. Pluralisme masyarakat Indonesia terjadi sudah lama dan sudah menjadi kebiasaan yang dapat menumbuhkan semangat nasionalisme. Kemajemukan juga telah menjadi landasan dan slogan dari bangsa, yakni "Bhinneka Tunggal Ika" (berbeda-beda tetapi tetap satu). ${ }^{31}$ Oleh sebab itu bangsa Indonesia dikenal sebagai sosok bangsa yang sangat pluralistik. ${ }^{32}$

Pancasila sila ketiga memberi makna bahwa perbedaan bahasa, suku, bangsa maupun agama tidak menjadi penghalang untuk tetap bersatu dan rukun. Begitu juga dalam Undang-Undang Dasar 1945 Pasal 28E, ayat (1) Setiap orang bebas memeluk agama dan beribadat menurut agamanya, ayat (2) Setiap orang berhak atas kebebasan meyakini kepercayaan, menyatakan pikiran dan sikap sesuai dengan hati nuraninya. 2. UUD pasal 29 ayat (2) Negara menjamin kemerdekaan tiap-tiap penduduk untuk memeluk agamanya masing-masing dan untuk beribadat menurut agamanya dan kepercayaannya itu.

Demikian juga dalam Undang-Undang Dasar (UUD) 1945 pasal 29 ayat 1 dan 2 merupakan landasan konstitusional dari kerukunan umat beragama. Pasal 29 ayat 1 dan 2 dari UUD 1945 memiliki arti bahwa Indonesia merupakan negara yang berdasar atas Ketuhanan yang Maha Esa dan menjamin kemerdekaan tiap-tiap penduduknya untuk memeluk agama dan beribadah sesuai dengan kepercayaannya. Selain UUD 1945, ada Pasal 22 UU No. 39 Tahun 1999 tentang HAM Pertama. Setiap orang bebas memeluk agamanya masing-masing dan untuk beribadah menurut agamanya dan kepercayaanya

${ }^{30}$ Widjaja, "Pluralitas Dan Tantangan Misi: Kerangka Konseptual untuk Pendidikan Agama Kristen dalam Masyarakat Majemuk.”

${ }^{31}$ Nurmiati dan Imam Suyitno, "Eksistensi Forum Kerukunan Umat Beragama Di Kabupaten Tana Toraja," Jurnal Tomalebbi: Jurnal Pemikiran, Penelitian Hukum, Pendidikan Pancasila dan Kewarganegaraan IV, no. 1 (2017): 78-92.

${ }^{32}$ Siti Makhmudah, "Upaya Masyarakat dalam Membina Kerukunan Antar Umat Beragama di Kelurahan Bangsal Kecamatan Pesantren Kota Kediri,” El-Wasathiya: Jurnal Studi Agama 4, no. 2 (2016): 167-192. itu. Kedua, negara menjamin kemerdekaan setiap orang memeluk agamanya masing-masing dan untuk beribadat menurut agamanya dan kepercayaannya itu. Melihat kondisi bangsa seiring dengan berjalannya waktu dan sejarah telah mencatat ada begitu banyak intoleransi yang menciderai kemajemukan. Pemerintah dengan berbagai alasan pertikaian yang terjadi menerbitkan tri kerukunan hidup beragama atau dapat disebut dengan istilah "trilogi kerukunan". Trilogi kerukunan ada dalam Peraturan bersama Menteri Agama dan Menteri dalam Negeri No 9 tahun 2006/ Nomor 8 tahun 2006.

Agama secara dogmatis mengajarkan "kasih untuk sesama" namun melahirkan sikap fundamentalis yang kemudian memicu munculnya praktik kekerasan. ${ }^{33} \mathrm{Hal}$ itu dapat mengakibatkan pertikaian bila agama dimengerti secara sempit dan mengarah pada pembenaran agamanya sendiri serta memperkeruh keadaan dengan menjelekkan serta menghina agama maupun pemeluk kepercayaan lain. Hal itu dapat memunculkan konflik horizontal yang lahir dari sikap dan nilai fundamental fanatisme agama yang berlebihan. ${ }^{34}$

Dalam berbangsa yang multikultural, seperti Indonesia, problem yang kristis dan tajam terjadi dari hubungan di antara suku bangsa yang berbeda kebudayaannya termasuk kepercayaan dan beragama. Hal itu memberikan pesan bagi orang percaya yang berada dalam otoritas hukum Negara Indonesia untuk terus menerapkan hukum kasih yang juga diterapkan dan diajarkan oleh Yesus dengan pokok ajaran yang memiliki esensi mengasihi Allah dan juga mengasihi manusia. $^{35}$ Orang Kristen dituntut untuk menunjukan secara terbuka identitas pribadinya sebagai orang yang mempercayai Yesus dan dituntut untuk membawa dampak kepada agama lain.

${ }^{33}$ Achmad Jainuri, Terorisme dan Fundamentalisme Agama: Sebuah Tafsir Sosial (Malang: Bayumedia Publishing, 2003), 118.

${ }^{34}$ Nasrullah, Agama dan Konflik Sosial: Studi Kerukunan Umat Beragama, Radikalisme dan Konflik Antarumat Beragama.

${ }^{35}$ Charles F. Pfeiffer dan Everett F. Harrison, ed., Tafsiran Alkitab Wycliffe Vol. 3 (Malang: Penerbit Gandum Mas, 2001), 38. 
Rukun di setiap lapisan masyarakat dalam beragama dapat dilakukan melalui upaya persamaan visi, pemahaman, dan kesadaran terhadap nilai agama, yaitu setiap agama secara esensial memiliki nilai-nilai universal yang dapat diterima oleh tiap-tiap pihak yang berbeda iman dan kepercayaan. $^{36}$ Kerukunan juga harus didasari rasa nasionalisme dengan menghormati setiap agama, suku maupun adat istiadat yang ada sehingga dapat terhindar dari persoalan pelik yang menyangkut kerukunan dalam disintegrasi horizontal yang multikultural. ${ }^{37}$

Pengakuan akan kebebasan memeluk kepercayan dan agama serta berkeyakinan merupakan hak dasar yang dijunjung negara. ${ }^{38}$ Kerukunan beragama akan menjadi suatu hal yang diperjuangkan melalui peningkatan pemahaman akan ajaran agama yang mengutamakan kerukunan pada masing-masing pengikut umat beragama, terlebih dapat memiliki sikap menjunjung tinggi perbedaan dan keanekaragaman pemahaman keagamaan. ${ }^{39}$ Semakin bagus nilai kerukunan dan keserasian intern ataupun antarumat beragama, serta antara umat beragama dengan negara akan memperkokoh persatuan dan kesatuan bangsa serta stabilitas keamanan nasional. ${ }^{40}$ Negara dalam hal ini pemerintah mempunyai tugas dan kewajiban melindungi hak dan kewajiban setiap warga negara untuk memeluk agama masingmasing serta memberikan arahan yang dapat menjadikan landasan beragama dengan aman dan tertib, berdasarkan undang-undang yang berlaku dan sah. ${ }^{41}$

\footnotetext{
${ }^{36}$ Khotimah, "Dialog dan Kerukunan Antar Umat Beragama.”

${ }^{37}$ Lia, Triposa, dan Lumingas, "Menciptakan Kerukunan Umat Beragama dalam Masyarakat Majemuk Melalui Pemaknaan Kasih Berdasarkan Matius 5:43-44.”

${ }^{38}$ Pamungkas, "Mengkritisi RUU Kerukunan Umat Beragama: Menjamin Atau Membatasi Kebebasan?"

${ }^{39}$ Arifuddin Ismail, "Refleksi Pola Kerukunan Umat Beragama (Fenomena Keagamaan di Jawa Tengah, Bali dan Kalimantan Barat)," Analisa: Journal of Social Science and Religion XVII, no. 02 (2010): 175-186.

${ }^{40}$ Sodli, "Kerukunan Umat Beragama Di Provinsi Nusa Tenggara Timur (NTT).”

${ }^{41}$ Harudin M., Khaidir, dan H. Rodja Abdul Natsir, "Merawat Keberagaman Menjaga Toleransi Meneropong Peran Forum Kerukunan Umat Beragama Kabupaten
}

\section{Keberagaman dan Kerukunan dalam Perspektif Alkitab}

Kerukunan adalah kehendak dan keinginan Tuhan dalam membawa orang yang percaya kepada berkat Tuhan (Mzm. 133:1-3). Tuhan yang adalah kasih sama seperti diungkapkan oleh pemazmur adalah Allah yang baik bagi semua orang (Mzm. 145:9). Penulis Perjanjian Baru khususnya Injil juga menyampaikan bahwa Allah menerbitkan matahari bagi orang baik maupun bagi orang jahat sekalipun tanpa ada perbedaan (Mat. 5:45). Ini membuktikan bahwa Allah tidak hanya bagi orang Kristen saja. ${ }^{42}$ Yesus sendiri menyatakan bahwa kemajemukan dan keanekaragaman ada, namun dalam menyikapi kemajemukan agama atau kepercayaan, Yesus tidak mengajarkan atau memerintah muridmuridnya untuk memusuhi dan menciderai agama dan isi ajarannya. Yesus mengajarkan ajaran yang menjadi dasar bagi perbuatan yang dilakukan terhadap Allah maupun kepada manusia yaitu dengan berlandaskan kasih, sebab kasih Allah adalah inti dari apa yang harus dilakukan dalam perjalanan kerohanian kepada Tuhan maupun kepada sesama. Dasar kasih akan melarutkan segala perbedaan, kasih juga mempersatukan orang-orang yang berpotensi hidup saling membenci, menyakiti bahkan saling membunuh. ${ }^{43}$ Yesus dalam pengajaranNya menempatkan manusia sebagai sesama yang harus dipandang dan diperlakukan sebagai objek kasih, dimana ukuran perlakuan kepada orang lain tidak mengenal batas agama, suku dan ras tetapi harus didasarkan pada kasih. ${ }^{44}$ Begitu rasul Paulus memberi nasihat kepada jemaat di Efesus dan Korintus agar memelihara kesatuan dalam keberlainan (Ef. 4:1-6 dan 1Kor. 12:12-31). Artinya, umat Kristen harus menghargai perbedaan dalam persekutuan serta menjunjung

Sikka," Academy of Education Journal 11, no. 2 (2020): 168181.

${ }^{42}$ Yewangoe, Agama dan Kerukunan.

${ }^{43}$ Christopher J. H. Wright, Becoming Like Jesus (Jawa Timur: Perkantas Jawa Timur, 2017).

${ }^{44}$ Butar-Butar dkk., "Pengajaran Tuhan Yesus Mengenai Toleransi dan Implementasinya Ditengah Masyarakat Majemuk." 
tinggi persatuan. ${ }^{45}$ Orang percaya dapat menjadi saksi atau teladan bagi masyarakat dengan bersikap bijak menghadapi berbagai perbedaan, menciptakan kerukunan antarumat beragama serta membangun komunikasi umat beragama dengan mencerminkan nilai kekristenan. ${ }^{46}$

Alkitab sebagai landasan orang percaya mengajarkan bahwa kasih adalah hukum terutama dari semua hukum (Im. 19:18; Mat. 19:19; 22:39; Mrk. 12:31; Luk. 10:27; Rm. 13:9; Gal. 5:14). Dalam kitab Yakobus justru lebih ditekankan bahwa jika seseorang menjalankan hukum yang utama maka orang tersebut berbuat baik (Yak. 2:8). Kasih juga adalah buah Roh (Gal. 5:22) dan seorang Kristen dituntut untuk menampilkan buah Roh tersebut dalam kehidupannya sehari-hari. ${ }^{47}$

\section{Kerukunan dan Misi Kristen}

Kerukunan antarumat beragama yang terjalin dengan toleransi menjadi suatu yang sangat penting untuk direalisasikan. ${ }^{48}$ Upaya menciptakan kerukunan atau sikap toleran adalah hal yang mutlak perlu dilakukan. ${ }^{49} \mathrm{Hal}$ ini disebabkan karena kerukunan merupakan syarat mutlak dan utama adanya persatuan. ${ }^{50}$ Kerukunan menjadi bagian untuk mencegah terjadinya pertikaian akibat perbedaan suku, agama, ras dan beragama yang didasari oleh masyarakat yang mempunyai kepribadian yang tinggi, penuh dengan sopan santun, budi

${ }^{45}$ Ruat Diana dkk., "Prinsip Hidup Kristen di Tengah Masyarakat yang Majemuk," Veritas Lux Mea (Jurnal Teologi dan Pendidikan Kristen) 1, no. 2 (2019): 9099.

${ }^{46}$ Riniwati Riniwati, "Iman Kristen dalam Pergaulan Lintas Agama," Jurnal Simpson: Jurnal Teologi dan Pendidikan Agama Kristen 1, no. 1 (2016): 21-36.

${ }^{47}$ Diana dkk., "Prinsip Hidup Kristen di Tengah Masyarakat yang Majemuk.”

${ }^{48}$ Sairin, Kerukunan Umat Beragama Pilar Utama Kerukunan Berbangsa: Butir-Butir Pemikiran.

${ }^{49}$ Musyarif, Hasnani Siri, dan Caerul Munzir, Kerukunan Umat Beragama di Kabupaten Tana Toraja (Analisis Hubungan Umat Islam dan Kristen) (Pare-Pare: IAIN Pare-Pare Nusantara Press, 2019), 4.

${ }^{50}$ Saidurrahman dan Arifinsyah, NALAR KERUKUNAN: Merawat Keberagaman Bangsa Mengawal NKRI, 64. pekerti, teposliro dan menghargai bentuk ibadah agama lain. ${ }^{51}$ Kerukunan menjadi impian bagi setiap manusia. Dalam mewujudkan hal tersebut maka dibutuhkan kerelaan untuk menjadi pengikut Kristus yang memiliki komitmen menjadi pembawa damai. ${ }^{52}$ Realitanya agama masih belum dipahami secara benar dan terkadang dieksklusifkan dengan tidak wajar yang juga disertai perasaan curiga terhadap penganut agama lain, sehingga mengakibatkan terjadinya berbagai macam pertikaian horizontal di tengah-tengah kemajemukan. Sementara itu, sikap over fanatisme di kalangan penganut agama masih sangat tinggi dan dominan kepada agama lain sehingga dapat menimbulkan disharmoni yang merugikan. ${ }^{53}$ Tuhan Yesus dalam teladan hidup dan ajaran-Nya mewariskan nilai toleransi yang merupakan tuntunan wajib bagi orang percaya untuk berpikir dan bertindak. Ajaran Tuhan Yesus tentang toleransi begitu tegas, lugas dan jelas sehingga mudah diterima. Karena itu gereja Tuhan seharusnya bebas dari aksi intoleransi apabila standar berpikir dan bertindaknya sesuai Alkitab. ${ }^{54}$

Kerukunan dan misi Kristen adalah bagian dari orang percaya yang menjadi saksi dan pelaku Amanat Agung Tuhan Yesus. Pelaksanaan mandat misi merupakan tanggungjawab yang dimandatkan oleh Tuhan Yesus Kristus kepada seluruh orang percaya yang menerima Yesus sebagai Tuhan. ${ }^{55}$ Pekabaran Injil adalah wujud cinta kasih manusia kepada Allah dan kepada sesamanya dengan sepenuhnya untuk keselamatan manusia dan untuk memuliakan Tuhan karena diberi kesempatan

${ }^{51}$ Mawardi Mawardi, "Reaktualisasi Kerukunan Antar Umat Beragama Dalam Kemajemukan Sosial," SUBSTANTIA: Jurnal Ilmu-Ilmu Ushuluddin 17, no. 1 (2015): 55-66.

${ }^{52}$ Lia, Triposa, dan Lumingas, "Menciptakan Kerukunan Umat Beragama dalam Masyarakat Majemuk Melalui Pemaknaan Kasih Berdasarkan Matius 5:43-44.”

${ }^{53}$ Victor Y. T. Tanja, Pluralisme Agama dan Problem Sosial (Jakarta: Penerbit Pustaka Cidesindo, 1998), 56.

${ }^{54}$ Butar-Butar dkk., "Pengajaran Tuhan Yesus Mengenai Toleransi dan Implementasinya Ditengah Masyarakat Majemuk."

${ }^{55}$ Seri Damarwanti, "Pandangan Rasul Paulus Tentang Jembatan Pengantar Injil. Kajian Misiologi Terhadap I Korintus 9:1-23," SANCTUM DOMINE: Jurnal Teologi 8, no. 2 (2019): 95-132. 
menjadi kawan sekerja-Nya. ${ }^{56}$ Misi yang telah diperintahkan oleh Allah adalah tugas dan tanggung jawab yang tidak dapat dihindari oleh orang Kristen, karena sesuai dengan mandat amanat yang datangnya dari Tuhan sendiri. ${ }^{57}$ Ditegaskan Stevanus, inisiatif dan penopang misi adalah Allah sendiri. Misi Kristen bukan produk gereja, tapi produk ilahi yang sifatnya mutlak dilakukan demi keselamatan umat manusia. ${ }^{58}$ Maka, tugas pemberitaan Injil sejatinya adalah tugas semua orang yang mengakui Yesus sebagai Tuhan tanpa terkecuali dimanapun mereka berada. ${ }^{59}$ Hal itu dipertajam oleh Rasul Paulus dalam surat 1 Korintus 9:16 "Bahwa pemberitaan Injil adalah sebuah keharusan dan bukan pilihan." ${ }^{\circ 0}$

Setiap orang percaya diwajibkan oleh Allah untuk memberitakan Injil Kristus. ${ }^{61}$ Orang percaya atau gereja sebagai penerima mandat misi untuk merealisasikan Amanat Agung Kristus harus memberitakan Injil sampai ke ujung bumi. ${ }^{62}$ Sebab Amanat Agung yang diberitakan bertujuan membawa jiwa bagi Tuhan. ${ }^{63}$ Seperti misi yang dilakukan oleh Yesus Kristus hingga masa kini memiliki tujuan supaya setiap orang yang belum mengenal dan percaya kepada Yesus Kristus dapat menerima kabar

\footnotetext{
${ }^{56}$ Stefany John Risna Abrahamsz dan Petronella Tuhumury, "Model Penginjilan dalam Yohanes 4:4-42 dan Implementasinya pada Masa Kini," Jurnal Jaffray 10, no. 2 (Oktober 1, 2012): 104-139.

${ }^{57}$ Handreas Hartono, "Mengaktualisasikan Amanat Agung Matius 28:19-20 dalam Konteks Era Digital," KURIOS [Jurnal Teologi dan Pendidikan Agama Kristen] 4, no. 2 (2018): 157-166.

${ }^{58}$ Kalis Stevanus, "Karya Kristus Sebagai Dasar Penginjilan Di Dunia Non-Kristen,” FIDEI: Jurnal Teologi Sistematika dan Praktika: Jurnal Teologi Sistematika dan Praktika 3, no. 1 (2020): 1-19.

${ }^{59}$ Kalis Stevanus, Lihatlah Sang Juruselamat Dunia (Yogyakarta: Diandra Kreatif, 2018), 23.

${ }^{60}$ Kejar Hidup Laia, "Pertumbuhan Gereja dan Penginjilan di Kepulauan Nias," FIDEI: Jurnal Teologi Sistematika dan Praktika 2, no. 2 (2019): 286-302.

${ }^{61}$ J. I. Packer, Penginjilan dan Kedaulatan Allah (Surabaya: Penerbit Momentum, 2003).

${ }^{62}$ Stevanus, "Karya Kristus Sebagai Dasar Penginjilan Di Dunia Non-Kristen.”

${ }^{63}$ David J. Bosch, Tranformasi Misi Kristen (Jakarta: BPK Gunung Mulia, 1998).
}

keselamatan yang diberikan oleh Allah. ${ }^{64}$ Stevanus mengungkapkan bahwa yang terkandung dalam perintah Amanat Agung itu adalah Injil untuk semua orang. ${ }^{65}$ Begitu juga dengan Peters menyatakan apapun alasannya misi tetap harus diberitakan dan disampaikan kepada semua manusia di seluruh muka bumi. Orang percaya melakukan tugas misi untuk mendeklarasikan Yesus yang membawa damai sejahtera dan sukacita keselamatan yang pada tujuan akhirnya setiap orang dapat menjadi bagian dari keluarga kerajaan Allah lewat komunitas gereja lokal. ${ }^{66}$ Gereja diharapkan memperhatikan dan mendukung pekabaran Injil ini, sebab pekerjaan tersebut adalah milik tubuh Kristus yang bertujuan menjangkau sebanyakbanyaknya orang yang belum mengenal Kristus. ${ }^{67}$ Mandat Amanat Agung tersebut berkaitan dengan kesanggupan dan tanggung jawab untuk menginjil yang termasuk didalamnya dipahami sebagai misi pemenangan jiwa bagi Tuhan. ${ }^{6}$ Karena Tuhan sebagai pondasi dan sumber misi, maka jelaslah jika landasan Allah yang kekal ini beranjak dari hati-Nya dan Allah juga berinisiatif untuk melaksanakan misi-Nya ${ }^{69}$

Pelaksanaan pekabaran Injil itu ditopang oleh kekuatan dan kuasa-Nya guna mencapai misi tersebut. ${ }^{70}$ Kuasa Roh Kudus bekerja bukan hanya memampukan seseorang menyampaikan kesaksian tentang Injil, melainkan juga mengubahkan hidup pribadinya sebagai saksi

${ }^{64}$ Mark Dever, Sembilan Tanda Gereja Yang Sehat (Surabaya: Penerbit Momentum, 2010), 87-88.

${ }^{65}$ Kalis Stevanus, Benarkah Injil Untuk Semua Orang (Yogyakarta: Diandra Kreatif, 2019), 25.

${ }^{66}$ I Putu Ayub Darmawan, "Jadikanlah Murid: Tugas Pemuridan Gereja Menurut Matius 28:18-20," Evangelikal: Jurnal Teologi Injili dan Pembinaan Warga Jemaat 3, no. 2 (2019): 144-153.

${ }^{67}$ Darsono Ambarita, Perspektif Misi dalam Perjanjian Lama dan Perjanjian Baru (Medan: Pelita Kebenaran Press, 2018), 1.

${ }^{68}$ Kosma Manurung, "Efektivitas Misi Penginjilan dalam Meningkatkan Pertumbuhan Gereja," DUNAMIS: Jurnal Teologi dan Pendidikan Kristiani 4, no. 2 (2020): 225233.

${ }^{69}$ Stephen Tong, Teologi Penginjilan (Surabaya: Penerbit Momentum, 2004).

${ }^{70}$ Kalis Stevanus, Panggilan Teragung: Pedoman dan Metoda Praktis untuk Memberitakan Kabar Baik Sampai ke Ujung Bumi (Yogyakarta: Andi Offset, 2019), 74. 
Kristus yang menjadi berkat bagi sesama. ${ }^{71}$ Melalui kuasa Roh Kudus, orang percaya akan dimampukan dan diperlengkapi untuk bersaksi bagi Kristus. ${ }^{72}$ Lantas perubahan hidup tersebut harus berpusat kepada Allah $^{73}$ dan membawa perubahan hidup seseorang lewat hidup yang menjadi berkat serta menanamkan kebaikan dalam setiap pergaulan di lapisan masyarakat. Keinginan Yesus bagi manusia adalah agar dapat menuntun manusia untuk mengerti dan menghidupi kebenaran Allah. $^{74}$ Orang yang dipanggil ke dalam terang-Nya sudah seharusnya memunculkan perbuatan baik dan benar dalam kehidupan dan terus berakar kuat di dalam kebenaran firman, hidup di dalam persekutuan, memiliki gaya hidup sebagai anak Tuhan serta hati yang peduli terhadap sesama sebagai bagian dari kawan sekerja Allah.

Landasan misi sangat penting bagi pengajaran dan pembinaan gereja. ${ }^{75}$ Misi Kristen sejatinya membawa orang percaya bertindak dalam ketaatan oleh kekuatan dan kuasa Allah. ${ }^{76}$ Hal itu seharusnya tidak melemahkan semangat memenangkan jiwa bagi Yesus Kristus. ${ }^{77}$ Namun memiliki tujuan untuk mendidik orang percaya agar memiliki sikap hati yang taat dan rendah

${ }^{71}$ Abrahamsz dan Tuhumury, "Model Penginjilan dalam Yohanes 4:4-42 dan Implementasinya pada Masa Kini."

${ }^{72}$ Heryanto David Lie, "Penggenapan Progresif Misi Allah Dalam Kisah Para Rasul 1: 8," Jurnal Jaffray 15, no. 1 (2017): 63-96.

${ }^{73} \mathrm{~J}$. Andrew Kirk, Apa Itu Misiologi? (Jakarta: BPK Gunung Mulia, 2015), 92.

${ }^{74}$ Yonatan Alex Arifianto dan Asih Rachmani Endang Sumiwi, "Peran Roh Kudus dalam Menuntun Orang Percaya kepada Seluruh Kebenaran Berdasarkan Yohanes 16 : 13," Diegesis: Jurnal Teologi Kharismatika 3, no. 1 (2020): 1-12.

${ }^{75}$ Markus Oci, "Implikasi Misiologi Dalam Pengembangan Kurikulum Agama Kristen Di Gereja Lokal," FIDEI: Jurnal Teologi Sistematika dan Praktika 2, no. 1 (2019): 84-102.

${ }^{76}$ Yakob Tomatala, Penginjilan Masa Kini Jilid I (Malang: Penerbit Gandum Mas, 2004).

${ }^{77}$ Hannas dan Rinawaty, "Menerapkan Model Penginjilan Pada Masa Kini," KURIOS [Jurnal Teologi dan Pendidikan Agama Kristen] 5, no. 2 (2019): 175-189. hati, dengar-dengaran akan firman Tuhan, ${ }^{78}$ serta hidup dalam persekutuan dengan Allah. ${ }^{79}$

Melalui hidup dalam kerukunan, kekristenan dapat dengan mudah diberitakan melalui gaya hidup dan aktualisasi yang mengarah pada mengahargai manusia. Sebab pemberitaan Injil adalah upaya mengkomunikasikan sikap hidup identitas Kristen yang benar dengan menghargai sesama dan tetap menyaksikan Yesus sebagai pribadi yang mengasihi manusia yang berdosa lewat kematian-Nya di kayu salib sebagai tanda kasih yang besar akan keselamatan manusia dapat dinyatakan ditengah pergaulan, sebagai bentuk mengkomunikasikan Injil dalam kerukunan yang tetap dijaga.

Orang percaya diharapkan dapat menjadi dampak bagi sekelilingnya terlebih dituntut untuk menampilkan dirinya sebagai saksi, terang dan garam dunia kepada keyakinan lain dalam semangat hubungan yang baik bagi kemajemukan. Sebab dengan menjadi berkat dapat membangun kesatuan, membangun komunikasi terkait isu-isu penting yang menjadi esensi dari ajaran agama dalam denominasi yang berbeda tanpa menimbulkan kemarahan. $^{80}$ Bercermin dari pelayanan Yesus, Dia membawa perubahan yang bertujuan untuk mengubah paradigma dan pemahaman orang agar saling mengasihi maupun hidup dalam kerukunan. ${ }^{81}$ Dengan terciptanya kerukunan, maka inti dari kabar baik dan perilaku pribadi orang yang percaya kepada Yesus dapat menjadi saksi dalam misi untuk membawa jiwa-jiwa datang kepada Yesus.

${ }^{78}$ Harls Evan Rianto Siahaan, "Hikmat sebagai Implikasi Pendidikan Kristiani: Refleksi 1 Raja-Raja 3:115," DUNAMIS: Jurnal Teologi dan Pendidikan Kristiani 1, no. 1 (2016): 15-30.

${ }^{79}$ Samgar Setia Budhi, "Eksegesis Mazmur 73: Pergumulan Orang Benar Tentang Kemakmuran Orang Fasik," HUPERETEES: Jurnal Teologi dan Pendidikan Kristen 1, no. 1 (2019): 1-16, http://sttkalimantan.ac.id/e-journal /index.php/huperetes/article/view/14.

${ }^{80}$ Yonatan Alex Arifianto dan Joseph Christ Santo, "Tinjauan Trilogi Kerukunan Umat Beragama Berdasarkan Perspektif Iman Kristen," Angelion: Jurnal Teologi dan Pendidikan Kristen 1, no. 1 (2020): 1-14.

${ }^{81}$ Arifianto, "Deskripsi Sejarah Konflik Horizontal Orang Yahudi dan Samaria." 


\section{KESIMPULAN}

Tak dapat dipungkiri bahwa Indonesia adalah suatu masyarakat majemuk. Menyadari hal tersebut, diperlukan interaksi aktif antara berbagai pihak dalam hal ini umat beragama untuk mewujudkan masyarakat yang rukun dan harmonis. Sebagai orang percaya, kasih Kristus menjadi dasar dalam hidup bermasyarakat guna menumbuh kembangkan sikap toleransi dan saling menghormati hak-hak setiap orang termasuk keyakinan. Realitas ini harus mengubah paradigma dan praktik dari misi Kristen modern. Misi Kristen harus tetap berpegang teguh pada Alkitab bahwa iman dalam Kristus sebagai persyaratan mutlak keselamatan harus tetap dipertahankan. Sebab itu, tidak ada alasan bagi orang percaya atau gereja untuk tidak menjalankan perintah misioner tersebut dengan tetap menjaga kerukunan beragama; untuk dapat menjadi berkat bagi orang yang belum mengenal Kristus.

\section{KEPUSTAKAAN}

Abrahamsz, Stefany John Risna, dan Petronella Tuhumury. "Model Penginjilan dalam Yohanes 4:4-42 dan Implementasinya pada Masa Kini.” Jurnal Jaffray 10, no. 2 (Oktober 1, 2012): 104-139.

Ambarita, Darsono. Perspektif Misi dalam

Perjanjian Lama dan Perjanjian Baru. Medan:

Pelita Kebenaran Press, 2018.

Arifianto, Yonatan. "Deskripsi Sejarah Konflik

Horizontal Orang Yahudi dan Samaria."

PASCA : Jurnal Teologi dan Pendidikan Agama

Kristen 16, no. 1 (Mei 29, 2020): 33-39.

Arifianto, Yonatan Alex, dan Joseph Christ

Santo. "Tinjauan Trilogi Kerukunan Umat

Beragama Berdasarkan Perspektif Iman

Kristen.” Angelion: Jurnal Teologi dan

Pendidikan Kristen 1, no. 1 (2020): 1-14.

Arifianto, Yonatan Alex, dan Asih Rachmani

Endang Sumiwi. "Peran Roh Kudus dalam

Menuntun Orang Percaya kepada Seluruh

Kebenaran Berdasarkan Yohanes 16 : 13.”

Diegesis: Jurnal Teologi Kharismatika 3, no. 1 (2020): 1-12.
Bosch, David J. Tranformasi Misi Kristen. Jakarta: BPK Gunung Mulia, 1998.

Budhi, Samgar Setia. "Eksegesis Mazmur 73: Pergumulan Orang Benar Tentang Kemakmuran Orang Fasik." HUPËRETẼS: Jurnal Teologi dan Pendidikan Kristen 1, no. 1 (2019): 1-16.

Butar-Butar, Rikardo Dayanto, Ester Lina Situmorang, Jabes Pasaribu, dan Manahan Uji Simanjuntak. "Pengajaran Tuhan Yesus Mengenai Toleransi dan Implementasinya Ditengah Masyarakat Majemuk.” REAL DIDACHE: Jurnal Teologi dan Pendidikan Agama Kristen 4, no. 1 (2019): 88-101.

Casram, Casram. "Membangun Sikap Toleransi

Beragama dalam Masyarakat Plural."

Wawasan: Jurnal Ilmiah Agama dan Sosial

Budaya 1, no. 2 (2016): 187-198.

Damarwanti, Seri. "Pandangan Rasul Paulus Tentang Jembatan Pengantar Injil. Kajian Misiologi Terhadap I Korintus 9:1-23." SANCTUM DOMINE: Jurnal Teologi 8, no. 2 (2019): 95-132.

Darmawan, I Putu Ayub. "Jadikanlah Murid: Tugas Pemuridan Gereja Menurut Matius 28:18-20." Evangelikal: Jurnal Teologi Injili dan Pembinaan Warga Jemaat 3, no. 2 (2019): 144-153.

Dever, Mark. Sembilan Tanda Gereja Yang Sehat. Surabaya: Penerbit Momentum, 2010.

Diana, Ruat, Katarina K., Yesi Tamara, dan Kiki Priskila. "Prinsip Hidup Kristen di Tengah Masyarakat yang Majemuk." Veritas Lux Mea (Jurnal Teologi dan Pendidikan Kristen) 1, no. 2 (2019): 90-99.

Hannas, dan Rinawaty. "Menerapkan Model Penginjilan Pada Masa Kini.” KURIOS [Jurnal Teologi dan Pendidikan Agama Kristen] 5, no. 2 (2019): 175-189.

Hartono, Handreas. "Mengaktualisasikan Amanat Agung Matius 28:19-20 dalam Konteks Era Digital.” KURIOS [Jurnal Teologi dan Pendidikan Agama Kristen] 4, no. 2 (2018): 157-166.

Herdiansah, Ari Ganjar, Junaidi -, dan Heni Ismiati. "Pembelahan Ideologi, Kontestasi Pemilu, dan Persepsi Ancaman Keamanan Nasional: Spektrum Politik Indonesia Pasca 
2014?" Jurnal Wacana Politik 2, no. 1 (Juni 14, 2017): 61-73.

Ismail, Arifuddin. "Refleksi Pola Kerukunan

Umat Beragama (Fenomena Keagamaan di Jawa Tengah, Bali dan Kalimantan Barat)." Analisa: Journal of Social Science and Religion XVII, no. 02 (2010): 175-186.

Jainuri, Achmad. Terorisme dan Fundamentalisme Agama: Sebuah Tafsir Sosial. Malang:

Bayumedia Publishing, 2003.

Khotimah, Khotimah. "Dialog dan Kerukunan Antar Umat Beragama." Jurnal Ushuluddin 17, no. 2 (2011): 214-224.

_. "Toleransi Beragama." Jurnal Ushuluddin 20, no. 2 (2013): 212-222.

Kirk, J. Andrew. Apa Itu Misiologi? Jakarta: BPK Gunung Mulia, 2015.

Laia, Kejar Hidup. "Pertumbuhan Gereja dan Penginjilan di Kepulauan Nias." FIDEI: Jurnal Teologi Sistematika dan Praktika 2, no. 2 (2019): 286-302.

Lia, Yudi Hendri, Reni Triposa, dan Gloria Gabriel Lumingas. "Menciptakan Kerukunan Umat Beragama dalam Masyarakat Majemuk Melalui Pemaknaan Kasih Berdasarkan Matius 5:43-44." PNEUMATIKOS: Jurnal

Teologi/Kependetaan 11, no. 1 (2020): 6170.

Lie, Heryanto David. "Penggenapan Progresif Misi Allah Dalam Kisah Para Rasul 1 : 8.” Jurnal Jaffray 15, no. 1 (2017): 63-96.

M., Harudin, Khaidir, dan H. Rodja Abdul Natsir. "Merawat Keberagaman Menjaga Toleransi Meneropong Peran Forum Kerukunan Umat Beragama Kabupaten Sikka." Academy of Education Journal 11, no. 2 (2020): 168-181.

Makhmudah, Siti. "Upaya Masyarakat dalam Membina Kerukunan Antar Umat Beragama di Kelurahan Bangsal Kecamatan Pesantren Kota Kediri." El-Wasathiya: Jurnal Studi Agama 4, no. 2 (2016): 167-192.

Manullang, Megawati. "Misi dalam Masyarakat Majemuk." Jurnal Teologi Cultivation 3, no. 2 (2019): 49-63.

Manurung, Kosma. "Efektivitas Misi Penginjilan dalam Meningkatkan Pertumbuhan
Gereja.” DUNAMIS: Jurnal Teologi dan Pendidikan Kristiani 4, no. 2 (2020): $225-$ 233.

Mawardi, Mawardi. "Reaktualisasi Kerukunan Antar Umat Beragama Dalam Kemajemukan Sosial.” SUBSTANTIA: Jurnal Ilmu-Ilmu Ushuluddin 17, no. 1 (2015): 55-66.

Mayasaroh, Kiki. "Toleransi Strategi dalam Membangun Kerukunan Antarumat Beragama di Indonesia." al-Afkar: Journal For Islamic Studies 3, no. 1 (2020): 77-88.

Musyarif, Hasnani Siri, dan Caerul Munzir.

Kerukunan Umat Beragama di Kabupaten Tana Toraja (Analisis Hubungan Umat Islam dan Kristen). Pare-Pare: IAIN Pare-Pare Nusantara Press, 2019.

Nasrullah, Adon. Agama dan Konflik Sosial: Studi Kerukunan Umat Beragama, Radikalisme dan Konflik Antarumat Beragama. Bandung: CV. Pustaka Setia, 2015.

Nazmudin, Nazmudin. "Kerukunan dan

Toleransi Antar Umat Beragama dalam Membangun Keutuhan Negara Kesatuan Republik Indonesia (NKRI)." Journal of Government $\mathcal{E}$ Civil Society 1, no. 1 (2017): 23-39.

Nurmiati, dan Imam Suyitno. "Eksistensi Forum Kerukunan Umat Beragama Di Kabupaten Tana Toraja." Jurnal Tomalebbi: Jurnal Pemikiran, Penelitian Hukum, Pendidikan Pancasila dan Kewarganegaraan IV, no. 1 (2017): 78-92.

Oci, Markus. "Implikasi Misiologi Dalam Pengembangan Kurikulum Agama Kristen Di Gereja Lokal.” FIDEI: Jurnal Teologi Sistematika dan Praktika 2, no. 1 (2019): 84102.

Packer, J. I. Penginjilan dan Kedaulatan Allah.

Surabaya: Penerbit Momentum, 2003.

Pamungkas, Setyo. "Mengkritisi RUU

Kerukunan Umat Beragama: Menjamin Atau Membatasi Kebebasan?" Refleksi Hukum: Jurnal Ilmu Hukum 8, no. 1 (2014): 103-114.

Pfeiffer, Charles F., dan Everett F. Harrison, ed. Tafsiran Alkitab Wycliffe Vol. 3. Malang: Penerbit Gandum Mas, 2001. 
Priatna, Mochamad Guruh Abdi, dan Hernawati RAS. "Tindak Pidana Penodaan Agama oleh Pemeluknya Melalui Media Internet Berdasarkan Undang-Undang Nomor 19 Tahun 2016 Tentang Perubahan Atas Undang-Undang No 11 Tahun 2018.” WACANA PARAMARTA: Jurnal Ilmu Hukum 16, no. 3 (2017): 139-148.

Riniwati, Riniwati. "Iman Kristen dalam Pergaulan Lintas Agama.” Jurnal Simpson: Jurnal Teologi dan Pendidikan Agama Kristen 1, no. 1 (2016): 21-36.

Saefullah, Ujang. "Dinamika Komunikasi dalam Mewujudkan Kerukunan Hidup Antarumat Beragama." Ilmu Dakwah: Academic Journal For Homiletic Studies 5, no. 1 (2011): 411444.

Saidurrahman, dan Arifinsyah. NALAR KERUKUNAN: Merawat Keberagaman Bangsa Mengawal NKRI. Jakarta: KENCANA, 2018.

Sairin, Weinata. Kerukunan Umat Beragama Pilar Utama Kerukunan Berbangsa: Butir-Butir Pemikiran. Jakarta: BPK Gunung Mulia, 2006.

_. Visi Gereja Memasuki Milenium Baru. Jakarta: BPK Gunung Mulia, 2002.

Semiawan, Conny R. Metode Penelitian Kualitatif. Jakarta: Grasindo, 2010.

Setara, Institut. Dari Radikalisme Menuju Terorisme. Jakarta: Pustaka Masyarakat Setara, 2015.

Siahaan, Harls Evan Rianto. "Hikmat sebagai Implikasi Pendidikan Kristiani: Refleksi 1 Raja-Raja 3:1-15.” DUNAMIS: Jurnal Teologi dan Pendidikan Kristiani 1, no. 1 (2016): 1530.

Sodli, Ahmad. "Kerukunan Umat Beragama Di Provinsi Nusa Tenggara Timur (NTT).” Analisa: Journal of Social Science and Religion 16, no. 1 (2009): 64-73.

Stevanus, Kalis. Benarkah Injil Untuk Semua Orang. Yogyakarta: Diandra Kreatif, 2019. . "Karya Kristus Sebagai Dasar Penginjilan Di Dunia Non-Kristen.” FIDEI: Jurnal Teologi Sistematika dan Praktika: Jurnal Teologi Sistematika dan Praktika 3, no. 1 (2020): 1 19.
Lihatlah Sang Juruselamat Dunia. Yogyakarta: Diandra Kreatif, 2018.

__. "Memaknai Kisah Orang Samaria Yang Murah Hati Menurut Lukas 10:25-37 Sebagai Upaya Pencegahan Konflik.” BIA': Jurnal Teologi dan Pendidikan Kristen Kontekstual 3, no. 1 (2020): 1-13.

_. "Mengimplementasikan Pelayanan Yesus dalam Konteks Misi Masa Kini Menurut Injil Sinoptik.” FIDEI: Jurnal Teologi Sistematika dan Praktika 1, no. 2 (2018): 284-298.

—. Panggilan Teragung: Pedoman dan Metoda Praktis untuk Memberitakan Kabar Baik Sampai ke Ujung Bumi. Yogyakarta: Andi Offset, 2019.

Tanja, Victor Y. T. Pluralisme Agama dan Problem Sosial. Jakarta: Penerbit Pustaka Cidesindo, 1998.

Tomatala, Yakob. Penginjilan Masa Kini Jilid I. Malang: Penerbit Gandum Mas, 2004.

Tong, Stephen. Teologi Penginjilan. Surabaya: Penerbit Momentum, 2004.

Widjaja, Fransiskus Irwan. "Pluralitas Dan Tantangan Misi: Kerangka Konseptual untuk Pendidikan Agama Kristen dalam Masyarakat Majemuk.” REGULA FIDEI: Jurnal Pendidikan Agama Kristen 4, no. 1 (2019): 1-13.

Wright, Christopher J. H. Becoming Like Jesus. Jawa Timur: Perkantas Jawa Timur, 2017.

Yewangoe, A. A. Agama dan Kerukunan. Jakarta: BPK Gunung Mulia, 2015. 